\title{
Carbonaceous aerosols and their potential role in atmospheric chemistry
}

\author{
D. J. Lary ${ }^{1}$ \\ Department of Geophysics and Planetary Sciences, Tel Aviv University, Tel Aviv, Israel
}

\author{
D. E. Shallcross \\ Centre for Atmospheric Science, Cambridge University, Cambridge, England, United Kingdom
}

\section{R. Toumi}

Department of Physics, Imperial College, London, United Kingdom

\begin{abstract}
This paper considers the nature of carbonaceous surfaces, the means by which they are activated, the nature of some functional groups that they support, and some reaction mechanisms that may be involved. Because of the strong affinity of carbonaceous surfaces for organic species and because of the ease with which compounds in a high oxidation state can oxidize the carbonaceous surface, it is highly likely that carbonaceous aerosols are interacting chemically with a range of organic species in ways that have, as yet, not been fully characterized but may significantly affect the oxidizing capacity of our atmosphere. If HONO is formed on the surface of carbonaceous aerosols then this could be a significant source of $\mathrm{HO}_{x}$ as $\mathrm{HONO}$ is readily photolyzed to give $\mathrm{OH}$, and it could explain the large values of $\mathrm{HONO}$ often observed in the troposphere. In general, the reduction of $\mathrm{NO}_{y}$ on carbonaceous aerosols is an important consideration, and it is addressed here.
\end{abstract}

\section{Introduction}

Carbonaceous aerosols (soot, charcoal, elemental carbon, etc.) are one of the most ubiquitous materials in our atmosphere. All combustion processes lead to the formation of carbonaceous material. As a result, between 10 and $50 \%$ of tropospheric particulates are carbonaceous, with particularly high levels being found in the urban atmosphere. Because of air traffic, carbonaceous aerosols (CA) are also found in the stratosphere. In his excellent introduction to CA, Goldberg [1985] has pointed out that the universality of CA is related to their refractory nature (very high melting point) and to their origin in burning processes. They can even be formed at temperatures of $200^{\circ} \mathrm{C}$ or less. They are generally very impure forms of carbon. Environmental charcoals have $\mathrm{H} / \mathrm{C}$ ratios of $0.25-0.69$ and $\mathrm{O} / \mathrm{C}$ ratios of 0.08-0.33 [Cope, 1979]. In addition, they can contain up to a percent or so of nitrogen and sulfur, as well as a host of metals and elements such as $\mathrm{Al}, \mathrm{Fe}, \mathrm{Ca}, \mathrm{Mg}$, $\mathrm{K}$, and $\mathrm{Si}$ [Gay et al., 1983, 1984; Goss and Eisenreich,

\footnotetext{
${ }^{1}$ Also at Centre for Atmospheric Science, Department of Chemistry, Cambridge University, Cambridge, CB2 1EW, England, U.K.

Copyright 1999 by the American Geophysical Union.

Paper number 1998JD100091

0148-0227/99/1998JD100091\$09.00
}

1997; Medalia and Rivin, 1982a,b; Medalia et al., 1982, 1983].

Active carbon is extensively used in various industrial processes, often as a reducing agent. It is therefore not surprising that recent laboratory studies have shown that $\mathrm{HNO}_{3}, \mathrm{NO}_{2}$ and $\mathrm{O}_{3}$ are also all reduced on CA [e.g., Smith and Chughtai, 1997; Ammann et al., 1995, 1997a,b; Rogaski et al., 1997; Chughtai et al., 1994; Tabor et al., 1993, 1994; Thlibi and Petit, 1994]. Modeling studies have shown that this could have a significant impact on atmospheric chemistry [Lary et al., 1997; Hauglustaine et al., 1996; Bekki, 1997]. Since the atmosphere is so strongly oxidizing, any process that can lead to the reduction of atmospheric constituents, such as CA, may have a significant impact on atmospheric chemistry as they oxidize the CA surface. The adsorptive property of black carbons to remove impurities from gases and solutions has been known for centuries. Such processes are therefore worthy of further study. This is particularly true if the reducing agent is also one of the most abundant particulates of the urban environment and is even present in the stratosphere. Examining the nature of these atmospheric processes is therefore important.

Some useful information on carbonaceous surfaces can be gained from the literature on activated carbon. However, considerable caution has to be applied when distinguishing atmospheric CA and activated carbon. 
They may have similarities but also important differences. One should not necessarily assume that CA are $100 \%$ carbon, or that they are crystalline with a well-known structure, since they are often incompletely burned biomass with a complex and varying composition of organic phases.

Although carbonaceous materials can vary considerably in their chemical reactivity, they do have several features in common. They are all carbonaceous, they can all be oxidized, they have a wide range of surface functional groups, and they typically have large surface areas.

Sections 2-10 consider the nature of carbonaceous surfaces, the means by which they are activated, some functional groups they support, and some reaction mechanisms that may be involved.

\section{Nature of the Surface}

A surface of carbon, or carbon plus hydrogen, is strongly hydrophobic. The presence of oxygen makes the surface more hydrophilic. CA may be acidic or basic depending on the way in which they are formed. Exposure of black carbon to temperatures between $200^{\circ}$ and $400^{\circ} \mathrm{C}$ yields an acidic surface whereas treatment at higher temperatures in $\mathrm{CO}_{2}$ followed by exposure to oxygen produces a basic form [Goldberg, 1985].

CA found in the environment are usually formed at high temperatures and come from a variety of sources, such as the combustion of plants, woods, fossil fuels, and industrially produced substances. The properties of the CA, such as the surface morphology and size distribution, reflect their origin and their history since they left the place of formation. Small submicron particles have usually been formed from combustion in the vapor phase (e.g., the combustion of a gas), and the larger particles which are bigger than $10 \mu \mathrm{m}$ reflect the structure of the burnt material, the so called char. Both may come from the same source, such as the combustion of plants and other biomass [Goldberg, 1985]. A detailed review of the chemical and physical properties of many carbonaceous materials can be found in the work of Mantell, [1968].

In $\mathrm{CA}$ the elemental carbon may be considered to be a disordered form of graphite (whereas the organic carbon content can not be thought of in this way). The degree of ordering within the carbonaceous material is reflected in a number of its properties. e.g., the density of a single crystal of graphite is $2.25 \mathrm{~g} \mathrm{~cm}^{-3}$, the density of coke is $2.05 \mathrm{~g} \mathrm{~cm}^{-3}$, and the density of carbon lamp black is $1.90 \mathrm{~g} \mathrm{~cm}^{-3}$ [Mantell, 1968]. Another example is the heat of oxidation of graphite to $\mathrm{CO}_{2}$ which is $32621 \mathrm{~J} \mathrm{~g}^{-1}$, whereas the heat of oxidation of amorphous to $\mathrm{CO}_{2}$ is more $33104 \mathrm{~J} \mathrm{~g}^{-1}$, and the heat of oxidation of wood charcoal to $\mathrm{CO}_{2}$ is greater still at $33807 \mathrm{~J} \mathrm{~g}^{-1}$ [Mantell, 1968].

$\mathrm{X}$-ray analysis of carbonaceous material shows that it has a graphite like structure with randomly orien- tated microcrystallites, with each of the platelets about $1 \mathrm{~nm}$ thick [de Vooys, 1983]. The disorder arises in the amorphous carbons from the smaller amount of carbon atoms in the layer planes, which have a mean diameter of the order of $2.5 \mathrm{~nm}$ [Goldberg, 1985]. Typically, only a percentage of the carbon surface is active, so poisoning is not very difficult. Usually, the smallest graphite crystallites are oxidized first thereby exposing more of the larger crystallites, which are less easily oxidized [ $v a n$ der Plas, 1970].

It is found that activated carbon absorbs hydrocarbon vapors in preference to water vapor [Mantell, 1968]. Heat is released when commercially available activated carbon samples are wetted. The heat release increases when the surfaces are highly oxidized. e.g., van Driel [1983] showed that when two different activated carbon samples were wetted by water between 34 and $35 \mathrm{~J} \mathrm{~g}^{-1}$ of carbon was released. However, after oxidation this increased to almost double, $66 \mathrm{~J} \mathrm{~g}^{-1}$ of carbon. This implies that part of the surface was of a more polar nature after oxidation. This explains why $\mathrm{CA}$ act as atmospheric cloud condensation nuclei, and it implies that atmospheric CA is oxidized.

In contrast, when the surface was wetted with toluene, instead of water, the heat released was between 129 and $131 \mathrm{~J} \mathrm{~g}^{-1}$ of carbon, with only a slight increase to between 135 and $138 \mathrm{~J} \mathrm{~g}^{-1}$ of carbon for the oxidized surface. The small increase in energy release was attributed to a possible increase in surface area. The heat release on wetting can provide energy for surface reactions.

The affinity of carbonaceous surfaces for hydrocarbons may have significant implications for atmospheric chemistry. If the effect of the $\mathrm{HNO}_{3}$ reduction on CA can be observed in atmospheric observations, as it seems from the work of Lary et al. [1997] and Hauglustaine et al. [1996], then it is also likely that atmospheric interactions of organic compounds with $\mathrm{CA}$ should be observed, because they should be taken up preferentially on CA. Goss and Eisenreich [1997] measured the sorption of polar and nonpolar volatile organic compounds (VOCs) to particles from a combustion source. A decrease in the sorption with increasing relative humidity was observed for all VOCs. The calculated sorption enthalpies suggested stronger sorption for polar compounds compared with nonpolar compounds of comparable volatility. Existing field data indicate that soot may significantly affect the environmental speciation of polycyclic aromatic hydrocarbons (PAHs) [Gustafsson et al., 1997]. The interactions between organic species and $\mathrm{CA}$ are likely to be quite complex. e.g., $M c D o w$ et al. [1996] have shown that 4 out of 10 of the major organic compound classes found in organic aerosols include compounds that accelerated the photodegradation of benz[a]anthracene.

The most reactive areas of the surface are likely to be where carbon is not exerting its full valency. These will often occur where the soot particles have 
exposed aliphatic and aromatic chains. These chains are stripped off as the CA is oxidized leading to the formation of $\mathrm{CO}, \mathrm{CO}_{2}$, and water. The time taken to strip off these chains is prolonged by an increased $\mathrm{H}$ content in the soot [Smith and Chughtai, 1996].

Carbonaceous surfaces absorb hydrocarbon vapors in preference to water vapor [Mantell, 1968]. It is therefore very likely that many atmospheric interactions are occurring between hydrocarbons and CA. We suggest that an important class of reactions may be with organic peroxides which can oxidize the carbonaceous aerosols and which are reduced in the process.

\section{Carbonaceous Aerosols as Cloud Condensation Nuclei}

There have been several studies of the state of water adsorbed on carbonaceous surfaces. e.g., active carbons and soot were studied by Berezin et al. [1997] who found that the state of adsorbed water is similar to the state of a stretched liquid. CA can act as cloud condensation nuclei (CCN). e.g., Konopka and Vogelsberger [1997] studied possible water condensation processes during the formation of aircraft contrails for different kinds of condensation centers. They found that soot particles with or without sulfuric acid can be more easily activated than small $\mathrm{H}_{2} \mathrm{O} / \mathrm{H}_{2} \mathrm{SO}_{4}$ droplets for atmospheric situations.

Condensation properties of ultrafine carbon particles in the Aitken range (particle diameters between 20 and $100 \mathrm{~nm}$ ) were investigated by Kotzick et al. [1997]. They studied condensation phenomena with dry monodisperse soot aerosols. After reaction with ozone, activation of soot particles occurred at lower supersaturations. Fourier Transform Infrared (FTIR) studies revealed that oxygen-containing functional groups are generated on the particle surface during oxidation, facilitating water uptake in the condensation process.

Lammel and Novakov [1995] found that the nucleation ability of chemically modified carbonaceous particles increased with increasing soluble mass fraction and was comparable to that of $\left(\mathrm{NH}_{4}\right)_{2} \mathrm{SO}_{4}$ when the soluble mass fraction exceeded about $10 \%$. The hygroscopicity of particles generated by combustion of diesel fuel in a diffusion flame increased when a sulfur-containing compound was added to the fuel. The CCN characteristics of diesel soot appear to be comparable to that of wood smoke aerosol. Karcher et al. [1996] analysed the primary contrail particles (aqueous solution droplets nucleated in situ, emitted insoluble combustion aerosols, and entrained background aerosols) and found that soot must be involved as ice-forming nuclei if the visibility criterion is to be fulfilled.

\section{Surface Activation}

Industrially, the basic method of activation is the introduction of further amounts of oxygen into the sur- face of carbon. This is done by submitting the carbon surface to oxidizing agents. These are either gaseous oxidizing agents, such as oxygen, ozone, air, water vapor, carbon dioxide, and nitrogen oxides, or solutions of oxidizing agents, such as nitric acid, a mixture of nitric and sulfuric acid, hydrogen peroxide, acidic potassium permanganate, chlorine water, sodium hypochlorite, and ammonium persulphate. Our atmosphere is a strongly oxidizing atmosphere that contains both categories of oxidizing agents in significant quantities. Therefore it should be perfectly able to activate, and keep activated, any CA that are present. Jankowska et al. [1991] reports that even a carbonaceous surface activated with ariel oxygen has many oxygen-containing surface functional groups.

Carbon oxidation is a complex heterogeneous process. Though the exact mechanism for the overall process is not fully understood, the reaction of carbon with oxygen can be written stoichiometrically as the following two exothermic reactions:

$$
\begin{aligned}
\mathrm{C}+\mathrm{O}_{2} & \longrightarrow \mathrm{CO}_{2} \Delta H_{R}=-387 \mathrm{~kJ} \mathrm{~mol}^{-1} \\
2 \mathrm{C}+\mathrm{O}_{2} & \longrightarrow 2 \mathrm{CO} \Delta H_{R}=-226 \mathrm{~kJ} \mathrm{~mol}^{-1}
\end{aligned}
$$

It is thought that both $\mathrm{CO}$ and $\mathrm{CO}_{2}$ are primary products [Smisek and Cerny, 1970] and that the $\mathrm{CO} / \mathrm{CO}_{2}$ ratio increases with temperature.

\section{Surface Functional Groups}

All carbonaceous materials, even pure materials like diamond and graphite, contain surface functional groups [van Driel, 1983]. A range of independent investigations has shown that a large variety of surface compounds are formed on the carbon surface. A characterization of the functional groups produced by the combustion of hexane has led to a more detailed understanding of the overall surface structure [Keifer et al. 1981, Akhter et al., 1984, 1985abc, 1986, Chughtai et al. 1994, Smith and Chughtai 1995, 1996, 1997].

Those containing oxygen compounds are particularly important because of their universal occurrence [Jankowska et al., 1991, p.82, and references therein]. The origin of these functional groups can be the starting material from which the CA were formed (this is particularly true for CA produced by raw materials rich in oxygen), or they can be introduced later. All commercial activated carbons also contain mineral matter. It is very likely that this applies to $\mathrm{CA}$ too, and these may have a significant effect on the rates of heterogeneous reactions on CA.

The number of oxygen containing surface groups will depend on the oxidizing agent and the type of surface. Nonetheless, two points should be noted. First, oxygencontaining surface functional groups typically represent $90 \%$ of the total amount of bound oxygen [van der Plas, 1970]. Second, several types of groups are found ir- 
respective of the type of active carbon or how it was modified.

It has been found that there are various types of carbons: those produced at low temperatures that typically have a negative surface charge and acidic behavior, and those produced at high temperatures that typically have a positive surface charge and basic behavior. The surface groups are found mostly at the edges of graphite type basal planes, which supports the idea of electronic interaction between surface groups. The acidity of one group influences neighboring groups and an overlap is possible between acidic strengths.

On air oxidation the carbonaceous surface becomes more acidic and therefore more polar. This is probably because of the formation of monocarboxylic or dicarboxylic acid groups [van Driel, 1983]. The reducing properties of activated carbon are slightly decreased by oxidation, perhaps owing to the formation of hydroquinone groups [van Driel, 1983]. Carbon groups at the rim of the carbon plane are destroyed, and $\mathrm{C}=0$ groups are formed in a yet unknown configuration. Figure 1 shows the principal types of acidic groups formed on carbonaceous surfaces; Figures 2 and 3 show models of carbonaceous surfaces. It can be seen that the surface<smiles>Cc1cc(C(=O)O)c(C)c(C)c1C</smiles>

Carboxylic<smiles>Cc1ccc2oc(=O)c(C)c(C)c2c1C</smiles>

Normal lactone<smiles>Cc1cc(O)c(C)c(C)c1C</smiles>

Phenolic<smiles>Cc1c(C)c(C)c2c(c1C)C(=O)OC2=O</smiles>

Carboxyluc anhydnde<smiles>CC1=C(C)c2c(C)c(C)cc3c2C(OC1=O)c1cc(O)c(C)c(C)c1-3</smiles>

Fluorescein-type lactone<smiles>C=C1C(C)=CC(=O)C(C)=C1C</smiles>

Quinonoid
Figure 1. Principal types of acidic surface groups [after Jankowska et al., 1991; Mattson and Mark, 1971]. groups present on the activated carbon surface are identical to those found on carbonaceous aerosol surfaces. The carboxyl surface groups make the $\mathrm{CA}$ acidic, and so they can take up greater quantities of ammonia, something that may be relevant in the troposphere. Noh and Schwarz [1990] and Bastick et al. [1977] showed that there was a relation between ammonia adsorption and the presence of surface carboxyl groups.

Smith and Chugtai [1995] used FTIR spectroscopy to study the structure and reactivity of black carbon (in the form of $n$-hexane soot). They found that the soot structure, as produced by high-temperature incomplete combustion is predominantly aromatic with a surface coverage by oxygen-containing functional groups of about 50\%. Sergides et al. [1987] also found that $50 \%$ of the CA surface was covered by oxygen containing groups and that the ratio of aromatic to aliphatic carbon in $n$-hexane soot is at least 9:1.

\section{Mechanisms for Surface Reactions}

The active sites on carbonaceous surfaces are thought to consist of carbon atoms that are not exerting their full valency. For example, the carbon-water reaction was explained by Long and Sykes [1948] by carbon atoms attached to the rest of the lattice by only three bonds. Such sites are likely to be found at the free edges of either the lamellar or the cross-linked aromatic rings, which are the basis of the carbonaceous structure.

Some processes occurring on the $\mathrm{CA}$ will be catalytic, and some will not. When considering the likely impact of noncatalytic processes, knowing the maximum number of carbon atoms that can be involved is important. Figure 4 shows the equivalent gas phase mixing ratio of carbon atoms if all the $\mathrm{CA}$ mass is assumed to be carbon for 1,10 and $100 \mathrm{ng} \mathrm{m} \mathrm{m}^{-3}$ as a function of the altitude. At the earth's surface (1000 mb) $1 \mathrm{ng}$ $\mathrm{m}^{-3}$ of carbon is equivalent to about $2 \mathrm{pptv}$ of carbon. During the Mauna Loa Observatory Photochemistry Experiment (MLOPEX) II campaign, values up to $200 \mathrm{ng} \mathrm{m}^{-3}$ of carbon can be observed with values of around $10 \mathrm{ng} \mathrm{m}^{-3}$ being quite typical, equivalent to between 20 and 200 pptv of carbon. As pressure drops exponentially with height this has increased to $10 \mathrm{pptv}$ at $15 \mathrm{~km}(100 \mathrm{mb})$. Blake and Kato [1995] report a typical Northern Hemisphere lower stratosphere value of $1.8 \mathrm{ng} \mathrm{m}^{-3}$ that corresponds to about $20 \mathrm{pptv}$ of carbon.

Smith and Chugtai [1995] have shown that FTIR methods are particularly well suited for following net changes in surface groups, and gas phase reactant/product concentrations. FTIR has been the key technique in determining the kinetics and mechanisms of some important heterogeneous reactions of black carbon with gas phase oxidant molecules. e.g., the reaction of $\mathrm{NO}_{2} / \mathrm{N}_{2} \mathrm{O}_{4}$ with soot follows a dual path mechanism, down to $2 \mathrm{ppm}$, which is reflected in the rate law, initial rate $R_{\imath}$ : 


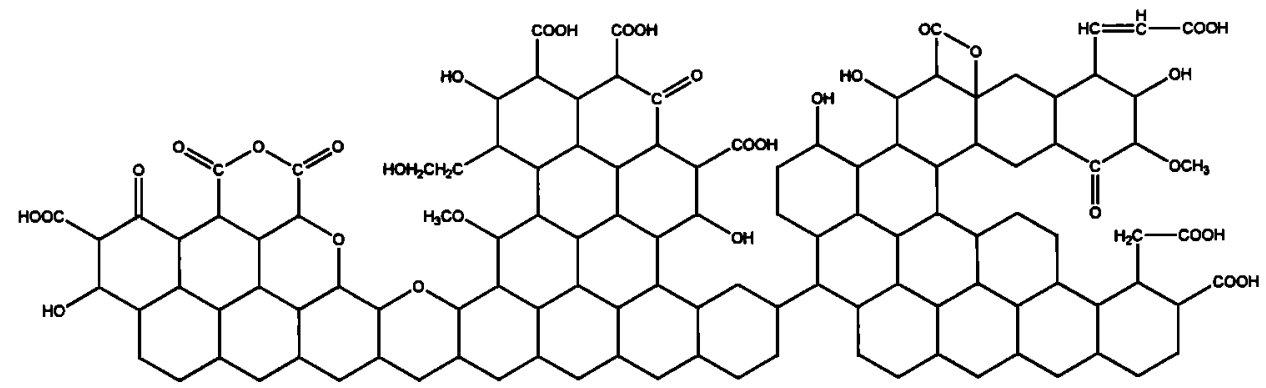

Figure 2. Model of a fragment of an oxidized active carbon surface (after Tarkovskaya et al., [1977] reproduced in English by Jankowska et al. [1991]).

$$
R_{i}=\left(k_{1}+k_{2}[\mathrm{soot}]^{1 / 2}\right) P_{N O_{2}}
$$

On the other hand, catalytic decomposition initiates the reaction with ozone, followed by the formation of surface carboxylic groups and gaseous $\mathrm{CO}_{2}$ and $\mathrm{H}_{2} \mathrm{O}$. The evidence suggests that dissociation of ozone yields a steadystate concentration of the excited oxygen atom, which is actually the oxidant. FTIR combined with chemical measurements has proven that a high solubility observed for carbon particles exposed to ozone has its origin in the hydrolysis of the surface carboxylics. Significant effects of simulated solar radiation on the reactions, especially in the soot $/ \mathrm{SO}_{2} / \mathrm{H}_{2} \mathrm{O} / \mathrm{O}_{2}$ system, has been revealed by FTIR. Infrared will continue its central role in the examination of increasingly complex systems containing black carbon, particularly through its interface with ancillary techniques.

\section{Carbon and Ozone}

Smith and Chughtai [1996] report that the reaction of ozone with a carbonaceous surface has three distinct stages. First, a rapid reaction with the surface produces functional groups such as hydroxyls and carboxylates. $\mathrm{O}_{3}$ begins the degradation of the soot particles by stripping them of aliphatic and aromatic chains with the for-

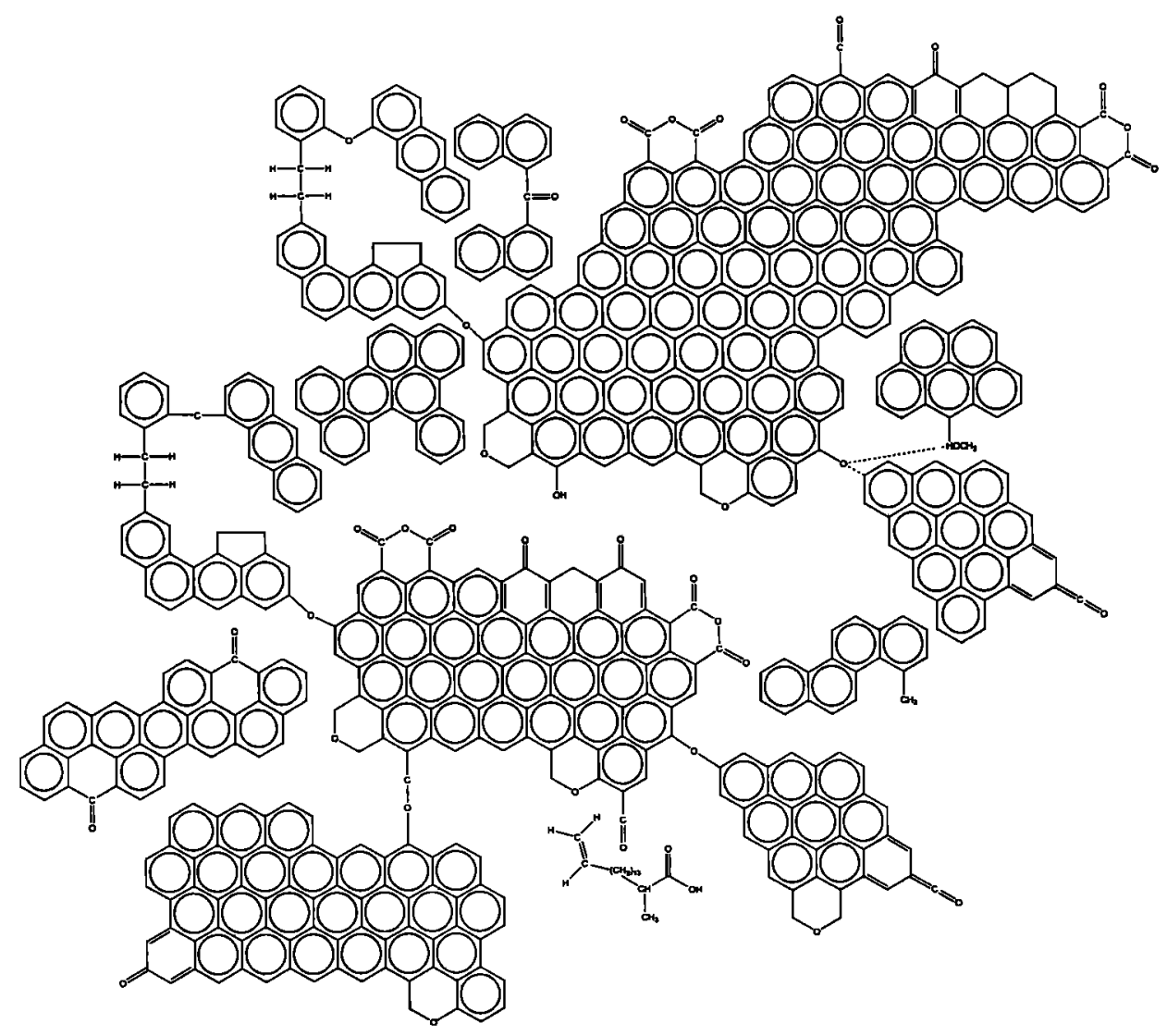

Figure 3. Two-dimensional model of n-hexane soot as formed in a flame [after Sergides et al., 1987]. 


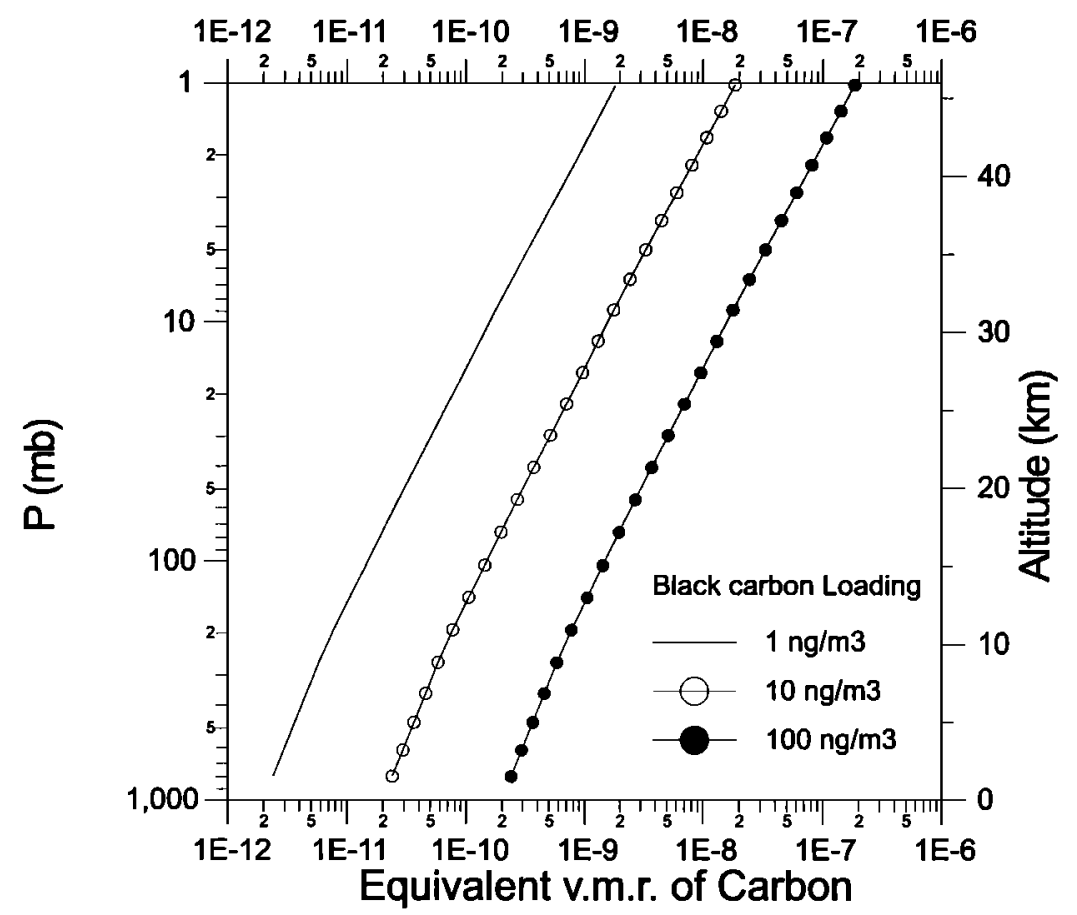

Figure 4. The equivalent gas phase mixing ratio of carbon atoms if all the CA mass is assumed to be carbon for 1,10 , and $100 \mathrm{ng} \mathrm{m}^{-3}$ as a function of altitude and atmospheric pressure. This is useful when considering whether or not chemical processes on CA will be significant even if they are not catalytic. v.m.r. means volume mixing ratio. Read $1 \mathrm{E}-12$ as $1 \times 10^{-12}$.

mation of $\mathrm{CO}_{2}$ and water. This stage is prolonged by an increased $\mathrm{H}$ content in the soot.

Second, a sharp increase in the $\mathrm{CO}_{2}$ released, which increases to a maximum and then starts to decrease. This unusual increase undoubtedly means several reactions are occurring. After stripping off the $\mathrm{H}$ atoms in the first stage the $\mathrm{O}_{3}$ oxidizes the $\mathrm{CO}$ to $\mathrm{CO}_{2}$ besides its continued reaction with the most vulnerable parts of the soot surface. This is consistent with a reduction in $\mathrm{CO}$ release during this stage.

Thirdly, the $\mathrm{CO}_{2}$ release begins to decrease, probably because the more reactive portions of the soot have now been oxidized and the more organized parts of the soot react at a slower rate.

Compared to soot that has not been exposed to $\mathrm{O}_{3}$, after 300 hours the ozonated soot experienced a decrease in particle size of $40 \%$ and a decrease in surface area of $37 \%$ [Sergides et al., 1987]. Smith and Chughtai [1996] have summarized the individual reactions identified as shown in Figure 5. The catalytic portion of the reaction can be written stoichiometrically as the highly exothermic reaction

$$
2 \mathrm{O}_{3} \longrightarrow 3 \mathrm{O}_{2} \quad \Delta H_{R}=-284 \mathrm{~kJ} \mathrm{~mol}^{-1}
$$

This catalytic reaction could have a profound impact on the stratosphere [Lary et al., 1997; Bekki, 1997]. Current assessment of the impact is hampered by our lack of knowledge about the true "average" nature of the soot. Bearing in mind that the soot lifetime in the lower stratosphere is of the order of months, it seems likely that very aged soot may have lost most of its reactivity as the surface degrades or becomes poisoned. We certainly expect the available surface area to decrease with time. Coal and amorphous carbon are rapidly attacked by $\mathrm{O}_{3}$, producing primarily water soluble acids similar to benzene carboxylic acids. It appears that $\mathrm{CO}_{2}$ and oxalic acids result from the ozonation of aromatic structures [Sergides et al., 1987, and references therein]. There is an approximately thirty fold increase in carboxylic acid surface groups when soot is exposed to $\mathrm{O}_{3}$, the increase in the particle's weight parallels this increase [Sergides et al., 1987]. The proportion of black carbon likely to be transformed into polycarboxylic acids decreases as the attack proceeds deeper into the particle.

Smith and Chughtai [1997] have examined the sootozone reaction at low concentrations to determine any influence of solar radiation on its products and kinetics. The effect of simulated solar radiation is to change the product distribution toward $\mathrm{CO}_{2(\mathrm{~g})}, \mathrm{CO}_{(\mathrm{g})}$, and $\mathrm{H}_{2} \mathrm{O}_{(\mathrm{g})}$ at the expense of soot surface functional groups formation. They concluded that the rapid diminution of ozone in soot's presence is unaffected by solar radiation.

\section{Carbon and $\mathrm{NO}_{2}$}

Chughtai et al. [1994] found that -ONO, -NOO, $\mathrm{NNO}_{2}$, and oxygen surface groups are formed and that 


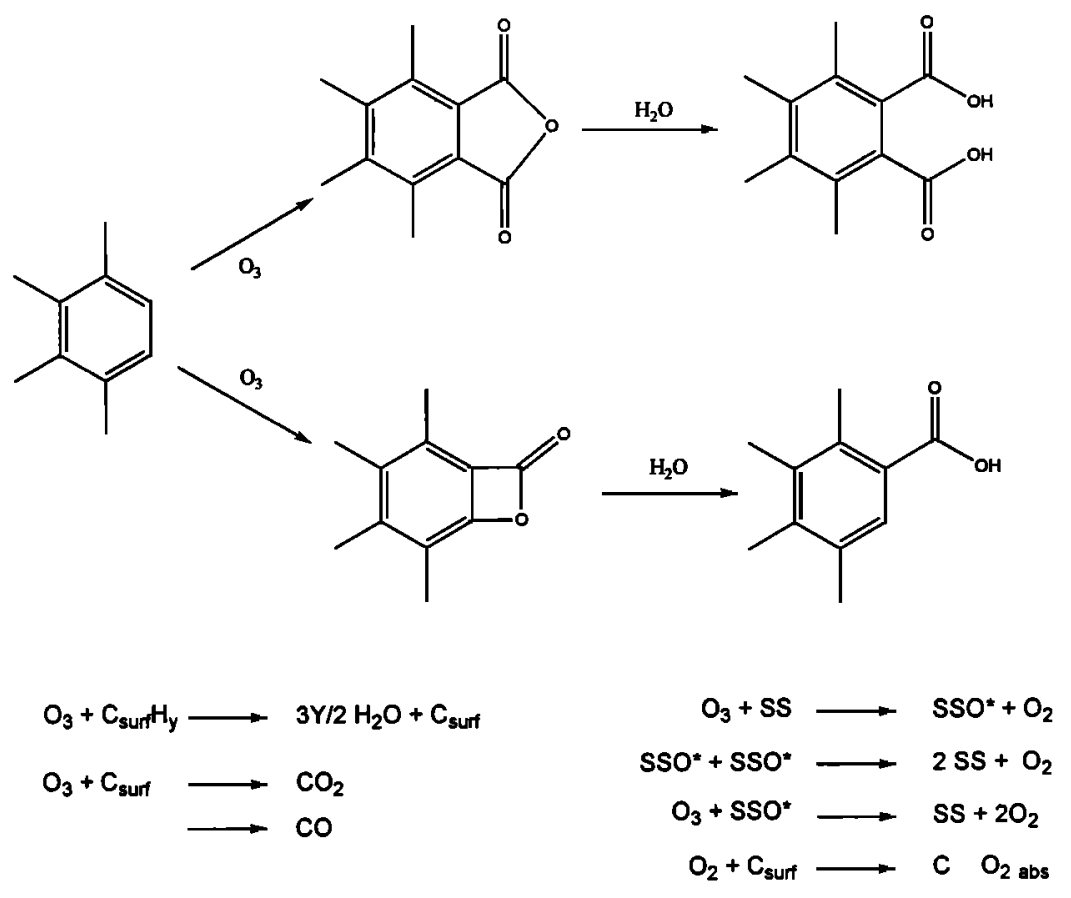

Figure 5. Individual reactions of ozone with CA from Smith and Chughtai [1996].

the presence of water plays a significant role leading to the formation of $\mathrm{NO}$ and $\mathrm{N}_{2} \mathrm{O}$ [see also Pires et al., 1996]. Tabor et al. [1993, 1994], Thlibi and Petit [1994], and Rogaski et al. [1997] have found that the reduction of $\mathrm{NO}_{2}$ to $\mathrm{NO}$ is very fast and therefore important. The aerosol studies by Kalberer et al. [1996] showed that it is slow when proceeding via a chemisorbed species which has been characterized by Ammann et al. [1995]. The chemisorption releases $100 \mathrm{~kJ} \mathrm{~mol}^{-1}$ and reversible adsorption $30 \mathrm{~kJ} \mathrm{~mol}^{-1}$ [Ammann et al., 1995, 1997a,b]. The NO was produced only slowly with a firstorder rate constant of around $10^{-4} \mathrm{~s}^{-1}$; yet even this small value could be significant when high levels of $\mathrm{CA}$ are present.

Rogaski et al. [1997] studied the reactivity and hydration properties of amorphous carbon in a low-pressure Knudsen cell reactor at room temperature $(298 \mathrm{~K})$. The reaction with $\mathrm{NO}_{2}$ had an observed $\gamma=0.11 \pm 0.04$. Treating the amorphous carbon with $\mathrm{NO}_{2}$ and $\mathrm{O}_{3}$ does not alter the $\mathrm{H}_{2} \mathrm{O}$ uptake, while treatment with $\mathrm{SO}_{2}$, $\mathrm{HNO}_{3}$, and $\mathrm{H}_{2} \mathrm{SO}_{4}$ increases significantly the $\mathrm{H}_{2} \mathrm{O}$ uptake.

HONO was first tentatively identified by Ammann et al. [1997a]. Then Ammann et al. [1998] and Gerecke et al. [1998] both showed that HONO is a major product of the soot $/ \mathrm{NO}_{2}$ interaction. The formation of HONO involves several intermediate steps that are not easy to separate.

If, as reported, HONO is formed, then this could be a significant source of $\mathrm{HO}_{x}$ as HONO is readily photolyzed to give $\mathrm{OH}$. Even if this process is not catalytic and only a fraction of the nitrogen incident on the $\mathrm{CA}$ leads to HONO formation, this could be a significant
$\mathrm{HO}_{x}$ source as at the Earth's surface $1 \mathrm{ng} \mathrm{m} \mathrm{m}^{-3}$ of carbon is equivalent to about $2 \mathrm{pptv}$ of carbon. During the MLOPEX II campaign, values up to $200 \mathrm{ng} \mathrm{m}^{-3}$ of carbon were observed, equivalent to about $400 \mathrm{pptv}$ of carbon. Tropospheric values of around $10 \mathrm{ng} \mathrm{m} \mathrm{m}^{-3}$ of black carbon are quite typical and are equivalent to about 20 pptv of carbon. Blake and Kato [1995] report a typical northern hemisphere lower stratosphere value of $1.8 \mathrm{ng} \mathrm{m}^{-3}$ that corresponds to about $20 \mathrm{pptv}$ of carbon. Since $\mathrm{OH}$ and $\mathrm{HO}_{2}$ are present in the atmosphere on the pptv scale these interactions could be a significant source of $\mathrm{HO}_{x}$.

J. Kleffmann [personal communication, 1998] have recently observed that the reaction of $\mathrm{NO}_{2}$ on dry soot produces large quantities of HONO in the gas phase ( $50 \%$ yields) at low pressure ( 2 torr) with some NO and adsorbed $\mathrm{HNO}_{3}$. At atmospheric pressure, $\mathrm{NO}$ yields are high (50\%) with only a small amount of HONO in the gas phase and 3-5\% adsorbed on the soot. In the presence of water ( $50 \%$ humidity), significant increases in HONO formation are observed (740 torr). They conclude that a consecutive reaction is occurring:

$$
\begin{aligned}
& \mathrm{NO}_{2} \longrightarrow \text { HONO } \\
& \mathrm{NO}_{2} \longrightarrow \mathrm{NO}
\end{aligned}
$$

where the major channel is

$$
\mathrm{NO}_{2}+\operatorname{soot} / \mathrm{H}_{2} \mathrm{O}_{(\mathrm{ads})} \rightarrow \mathrm{HONO}+\operatorname{soot}_{(\text {ox. })}
$$

and the minor channel is

$$
2 \mathrm{NO}_{2}+\mathrm{H}_{2} \mathrm{O}_{(\text {ads })} \rightarrow \mathrm{HONO}+\mathrm{HNO}_{3}
$$


followed by

$$
\mathrm{HONO}+\operatorname{soot}_{(\text {reactive) }}^{\rightarrow} \mathrm{NO}+\operatorname{soot}_{(\text {ox. }}
$$

where $\operatorname{soot}_{(\mathrm{ox} .)}$ denotes oxidized soot.

\section{Carbon and Nitric Acid}

Rogaski et al. [1997] have studied the reduction of $\mathrm{HNO}_{3}$ on a carbonaceous surface. They report that the main products are $\mathrm{NO}, \mathrm{NO}_{2}$, and $\mathrm{H}_{2} \mathrm{O}$. Constructing some overall stoichiometric reactions that are exothermic is possible, e.g.,

$$
\begin{array}{rll}
\mathrm{HNO}_{3}+\mathrm{O}_{3} & \stackrel{\mathrm{CA}}{\longrightarrow} & \mathrm{HONO}+2 \mathrm{O}_{2} \\
2 \mathrm{HNO}_{3}+2 \mathrm{O}_{3} & \stackrel{\mathrm{CA}}{\longrightarrow} & \mathrm{NO}+\mathrm{NO}_{2}+\mathrm{H}_{2} \mathrm{O}+4 \mathrm{O}_{2}
\end{array}
$$

which are both exothermic at $298 \mathrm{~K}$. No detailed reaction mechanism is given by Rogaski, but on basis of the findings of Chughtai et al. [1994], who studied the interaction of soot with $\mathrm{NO}_{2}$ and $\mathrm{N}_{2} \mathrm{O}_{4}$, it is likely that ONO, $-\mathrm{NOO}$, and $-\mathrm{NNO}_{2}$ surface groups will be formed.

Rogaski et al. [1997] studied the reactivity and hydration properties of amorphous carbon in a low-pressure Knudsen cell reactor at room temperature $(298 \mathrm{~K})$. They found that the reaction of $\mathrm{HNO}_{3}$ had an observed $\gamma=0.038 \pm 0.008$.

As mentioned for $\mathrm{NO}_{2}$ reacting on the surface of $\mathrm{CA}$, if HONO is formed, then this could be a significant source of $\mathrm{HO}_{x}$ as $\mathrm{HONO}$ is readily photolyzed to give $\mathrm{OH}$. Even if this process is not catalytic and only a fraction of the nitrogen incident on the CA leads to HONO formation, Figures 6 and 7 show that this could be a significant source of $\mathrm{OH}$ and HONO. This is the case even if the CA surface area used is as low as $0.01 \mu \mathrm{m}^{2} \mathrm{~cm}^{-3}$ and the reaction probability is as low as $10^{-3}$. This may explain why large values of HONO [e.g., Harrison and Kitto, 1994] are often observed in the troposphere in regions where the numerical models do not predict such large amounts of HONO. If hydrogen is abstracted from $\mathrm{HNO}_{3}$ then $\mathrm{NO}_{3}$, a nighttime oxidizing agent, could be released.

Kinoshita [1988] and Mahajan et al. [1978] report that treatment with $\mathrm{HNO}_{3}$ is one of the most effective ways to make the carbon surface acidic. The treatment of a carbonaceous surface with $\mathrm{HNO}_{3}$ does not affect their physical morphology but rather alters their surface chemical properties.

During the Transport and Atmospheric Chemistry Near the Equatorial Atlantic (TRACE A) campaign, Smyth et al. [1996] observed high NO concentrations in the upper troposphere, over a region characterized by intense biomass burning. These workers have concluded that one possible explanation for these results is that $\mathrm{HNO}_{3}$ is being rapidly recycled back to $\mathrm{NO}_{x}$ in the upper troposphere. In addition, Jacob et al. [1996] have also come to the same conclusion from the TRACE A campaign. In the 8-12 $\mathrm{km}$ region these work-

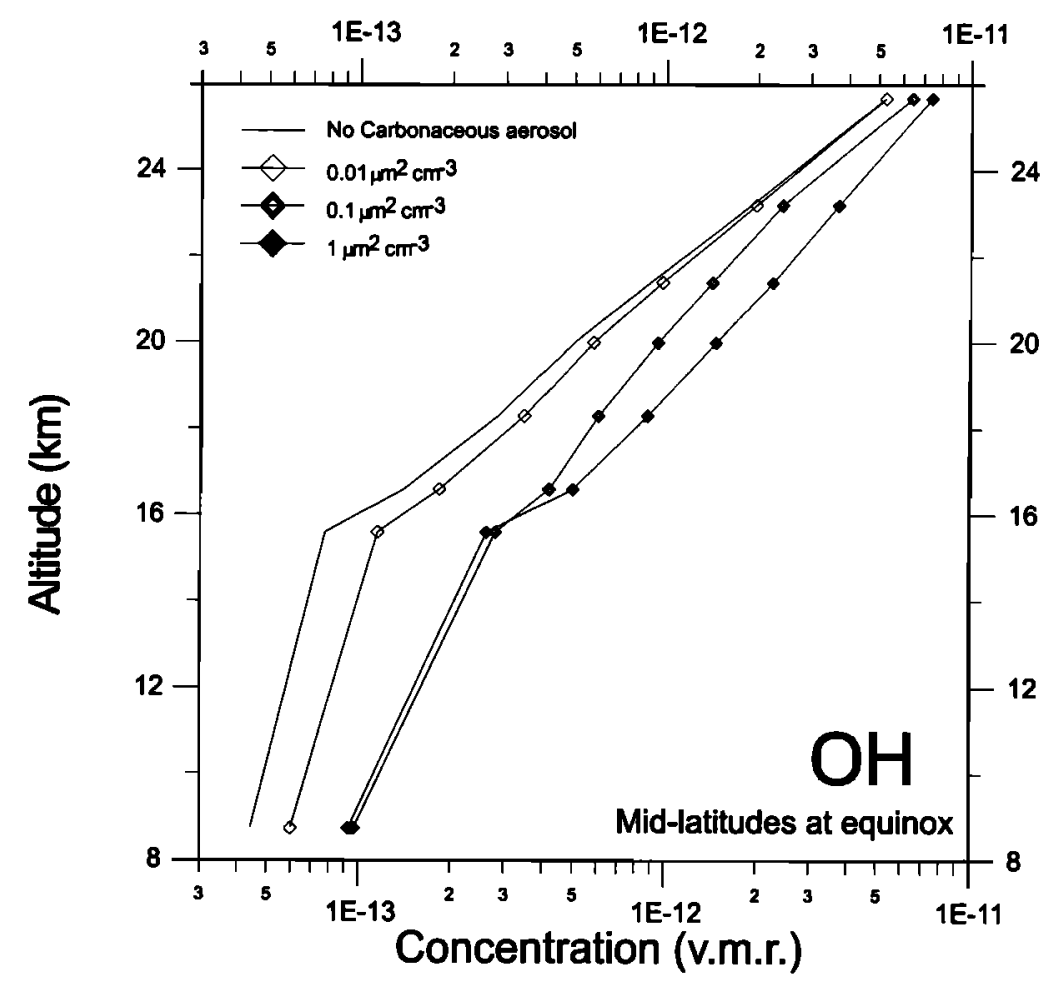

Figure 6. The calculated effect at midlatitudes at equinox on the concentration of $\mathrm{OH}$ if the postulated reaction $\mathrm{HNO}_{3}+\mathrm{O}_{3} \rightarrow \mathrm{HONO}+2 \mathrm{O}_{2}$ is included on carbonaceous aerosols with a reaction probability of only $10^{-3}$. 


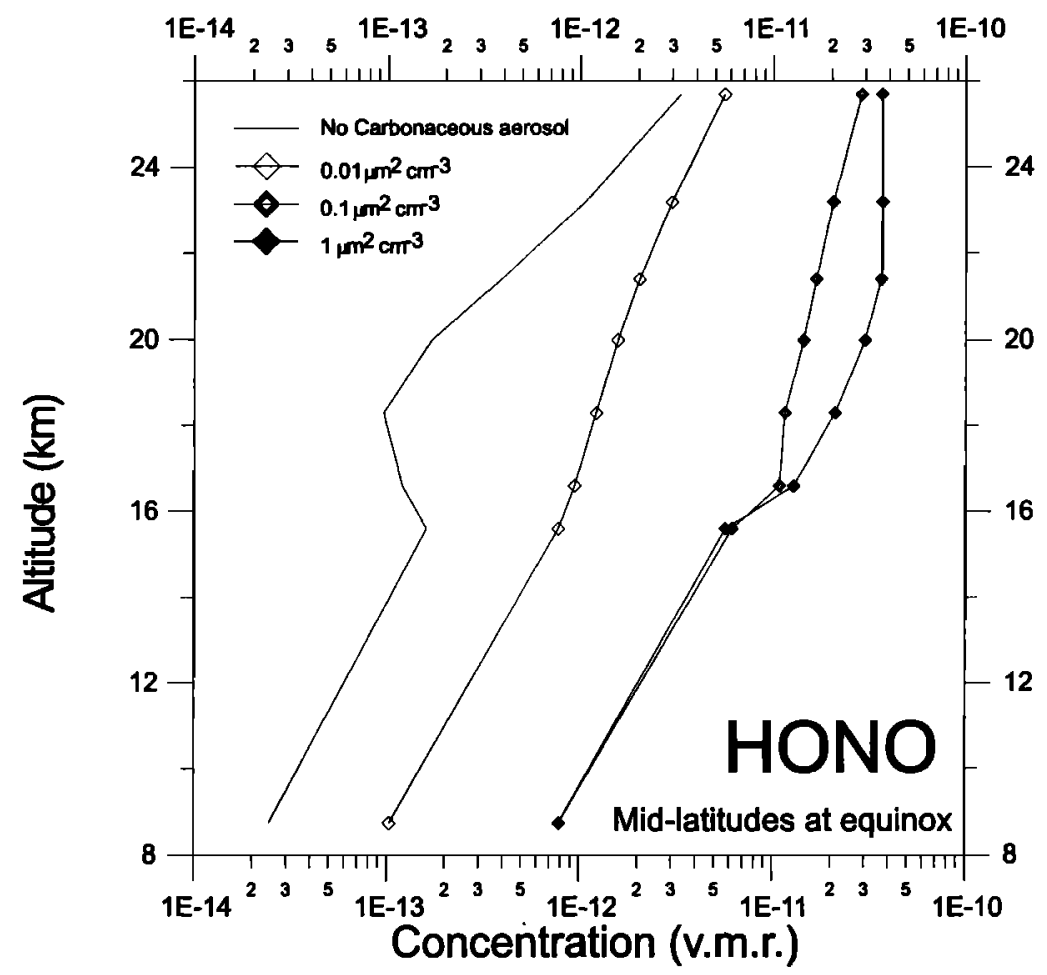

Figure 7. The calculated effect at mid-latitudes at equinox on the concentration of HONO if the postulated reaction $\mathrm{HNO}_{3}+\mathrm{O}_{3}-\mathrm{HONO}+2 \mathrm{O}_{2}$ is included on carbonaceous aerosols with a reaction probability of only $10^{-3}$.

ers note that the median conversion of $\mathrm{NO}_{x}$ to $\mathrm{HNO}_{3}$ from a model is $57 \mathrm{ppt}_{\text {day }}{ }^{-1}$ whereas the median $\mathrm{HNO}_{3}$ levels observed are $59 \mathrm{ppt}$. Therefore the lifetime of $\mathrm{HNO}_{3}$ needs to be of the order of a day, whereas its lifetime with respect to reaction with $\mathrm{OH}$ and photolysis is of the order of 12 days. During biomass burning events, large quantities of black carbon are produced, and it is extremely likely that during deep convective events, elevated levels of black carbon are brought up to the upper troposphere. The conversion of $\mathrm{HNO}_{3}$ to $\mathrm{HONO} / \mathrm{NO}_{2} / \mathrm{NO}$ and the conversion of $\mathrm{NO}_{2}$ to $\mathrm{HONO} / \mathrm{NO}$ on black carbon could well be the missing mechanism noted by Jacob et al. [1996] and Smyth et al. [1996] to explain the elevated levels of NO observed in this region.

The calculations shown in Figures 6 and 7 were made using the chemical model AUTOCHEM for midlatitude equinox conditions. No family or photochemical equilibrium assumptions are made. All species are time integrated separately with a $15 \mathrm{~min}$ time step. The time integration scheme used is an adaptive timestep Burlisch-Stoer [Stoer and Burlisch, 1980] scheme specifically designed for integration of stiff systems after Press et al. [1992]. The time integration package is as accurate as the often used Gear [1971] package but faster. Photolysis rates are calculated by using full spherical geometry and multiple scattering as described by Lary and Pyle [1992ab] after Meier et al. [1982], Nicolet et al. [1982], and Anderson [1983]. The average photolysis rate over a model time step is calculated using 10-point Gaussian quadrature as described by Press et al. [1992]. AuToChem has also been used to perform for the first time four-dimensional variational analysis of chemical species [Fisher and Lary, 1995]. The reactions on the carbonaceous surface are treated in the same way as reactions on the surface of polar stratospheric clouds (PSCs) are, a surface area is specified, as well as a reaction probability. Because this is a preliminary study, no account is taken of surface ageing or poisoning, although both of these are likely to be important. For this to be treated accurately more kinetic data is required, which, as yet is unavailable. The model contains a total of 56 species with a total of 320 reactions. Fifty-one species are integrated, namely, $\mathrm{O}\left({ }^{1} \mathrm{D}\right), \mathrm{O}\left({ }^{3} \mathrm{P}\right), \mathrm{O}_{3}, \mathrm{~N}$, $\mathrm{NO}, \mathrm{NO}_{2}, \mathrm{NO}_{3}, \mathrm{~N}_{2} \mathrm{O}_{5}, \mathrm{HONO}, \mathrm{HNO}_{3}, \mathrm{HO}_{2} \mathrm{NO}_{2}, \mathrm{Cl}$, $\mathrm{Cl}_{2}, \mathrm{ClO}, \mathrm{ClOO}, \mathrm{OClO}, \mathrm{Cl}_{2} \mathrm{O}_{2}, \mathrm{ClNO}_{2}, \mathrm{ClONO}_{2}, \mathrm{HCl}$, $\mathrm{HOCl}, \mathrm{CH}_{3} \mathrm{OCl}, \mathrm{Br}, \mathrm{Br}_{2}, \mathrm{BrO}, \mathrm{BrONO}_{2}, \mathrm{BrONO}, \mathrm{HBr}$, $\mathrm{HOBr}, \mathrm{BrCl}, \mathrm{H}_{2}, \mathrm{H}, \mathrm{OH}, \mathrm{HO}_{2}, \mathrm{H}_{2} \mathrm{O}_{2}, \mathrm{CH}_{3}, \mathrm{CH}_{3} \mathrm{O}$, $\mathrm{CH}_{3} \mathrm{O}_{2}, \mathrm{CH}_{3} \mathrm{OH}, \mathrm{CH}_{3} \mathrm{OOH}, \mathrm{CH}_{3} \mathrm{ONO}_{2}, \mathrm{CH}_{3} \mathrm{O}_{2} \mathrm{NO}_{2}$, $\mathrm{HCO}, \mathrm{HCHO}, \mathrm{CH}_{4}, \mathrm{CH}_{3} \mathrm{Br}, \mathrm{CF}_{2} \mathrm{Cl}_{2}, \mathrm{CO}, \mathrm{N}_{2} \mathrm{O}, \mathrm{CO}_{2}$, and $\mathrm{H}_{2} \mathrm{O}$.

\section{Entrainment Within Liquid Drops}

Since oxidation of the CA makes them hydrophilic, it is very likely that $\mathrm{CA}$ will become incorporated into liquid drops, whether these are rain drops or sulphate aerosols. This is what is observed [e.g., Karcher et al., 1996]. It is also found that soot embedded in a liquid 
coating containing $\mathrm{H}_{2} \mathrm{SO}_{4}$ and $\mathrm{HNO}_{3}$ triggers heterogeneous freezing of water ice and leads to visible contrails [Karcher, 1996].

For a reaction to occur on a $\mathrm{CA}$ embedded within a droplet, several mass transfer steps must take place [Seinfeld, 1986, Hanson et al., 1994]:

1. Gaseous species must diffuse from the bulk gas to the surface of the droplet. This has a timescale given by

$$
\tau_{d g}=\frac{r_{p}^{2}}{4 D_{g}}
$$

where the radius of the drop is $r_{p}$ and the typical molecular diffusivity $D_{g}$ is $0.1 \mathrm{~cm}^{2} \mathrm{~s}^{-1}$. So for a droplet with a radius of $0.1 \mu \mathrm{m}$ the timescale is just $25 \mathrm{~ns}$.

2. Transfer across the gas-liquid interface must take place. This depends on the Henry's law coefficient and the accommodation coefficient via the relationship

$$
\tau_{p}=D_{a}\left(\frac{4 R T H}{\alpha c}\right)^{2}
$$

where $D_{a}$ is the aqueous phase diffusion coefficient of the species initially in the gas phase, typically around $10^{-5} \mathrm{~cm}^{2} \mathrm{~s}^{-1} . c$ is the average speed of gas molecules given by kinetic theory $(c=\sqrt{8 R T / \pi M})$. $H$ is the Henry's law coefficient; as $H$ increases, so does $\tau_{p}$. If we take the accommodation coefficient $\alpha$ to have its maximum value of 1 , then for $\mathrm{HNO}_{3} \tau_{p}$ is of the order of a second or so, whereas for $\mathrm{O}_{3}$ and $\mathrm{NO}_{2}, \tau_{p}$ is approximately $10^{-15} \mathrm{~s}$.

3. If ionization of the species occurs, it will be rapid for strong acids such as $\mathrm{HNO}_{3}$.

4. The dissolved species in the aqueous phase diffuse. The characteristic time for aqueous-phase diffusion is

$$
\tau_{d a}=\frac{r_{p}^{2}}{\pi^{2} D_{a}}
$$

so for a radius of $1 \mu \mathrm{m}, \tau_{d a}$ is just $10^{-2} \mathrm{~s}$.

5. If a chemical reaction occurs as these processes happen sequentially, the overall rate is the rate of the slowest step. In the case of CA for molecules such as $\mathrm{HNO}_{3}$ with large Henry's law coefficients, the slowest step is likely to be the transfer across the gas-liquid interface or the reaction at the CA surface embedded in the drop. Even so, this is still quite rapid, occurring on the timescale of a few seconds. For molecules such as $\mathrm{NO}_{2}$ and $\mathrm{O}_{3}$ with small Henry's law coefficients, the slowest step is likely to be the reaction at the CA surface embedded in the drop. For droplets with a radius of less than a $\mu \mathrm{m}$, diffusion of the dissolved species within the aqueous phase is rapid.

Therefore the fact that CA become entrained within droplets does not necessarily mean that they will no longer be effective in chemically processing the surrounding air. However, a relevant question which needs further kinetic investigation is how reactive will the carbonaceous "core" be once entrained within a liquid aerosol?

\section{Summary and Suggestions}

Carbonaceous aerosols are readily oxidized in the atmosphere by both gas and aqueous phase oxidizing agents. In the process the oxidizing agents are themselves reduced, something that in some cases does not rapidly occur in the atmosphere. e.g., $\mathrm{HNO}_{3}$ is reduced to $\mathrm{NO}_{2}$ on carbonaceous aerosols, something that will normally occur only slowly by reaction with $\mathrm{OH}$ or by photolysis.

The oxidation of the carbonaceous aerosols leads to the formation of a range of polar surface groups, such as carboxylates, which cause the carbonaceous aerosols to become more hydrophilic and acidic. As a result, they can act as effective cloud condensation nuclei. Newly formed carbonaceous aerosols are much more reactive as they contain more aromatic and aliphatic chains and sites where carbon is not exerting its full valency. This oxidation is slower when more $\mathrm{H}$ is present. Once the sites where carbon is not exerting its full valency are oxidized (with the associated release of $\mathrm{CO}, \mathrm{CO}_{2}$ and $\mathrm{H}_{2} \mathrm{O}$ ) the less reactive, graphite like, sheets become more exposed. As well as the mass loss Because of the formation of $\mathrm{CO}$ and $\mathrm{CO}_{2}$, there is a mass gain by the formation of groups such as surface carboxylates.

If HONO is formed on the surface of CA, then this could be a significant source of $\mathrm{HO}_{x}$ as HONO is readily photolyzed to give $\mathrm{OH}$. Even if this process is not catalytic and only a fraction of the nitrogen incident on the CA leads to HONO formation, this could be a significant source of $\mathrm{OH}$ and HONO. This is the case even if the CA surface area used is as low as $0.01 \mu \mathrm{m}^{2} \mathrm{~cm}^{-3}$ and the reaction probability is as low as $10^{-3}$. This may explain why large values of HONO are often observed in the troposphere in regions where the numerical models do not predict such large amounts of HONO. If the hydrogen is abstracted then $\mathrm{NO}_{3}$, a nighttime oxidizing agent, could be released.

Carbonaceous surfaces absorb hydrocarbon vapors in preference to water vapor. It is therefore very likely that many atmospheric interactions are occurring between hydrocarbons and carbonaceous aerosols. An important class of reactions may be with organic peroxides which can oxidize the carbonaceous aerosols and which are reduced in the process. Also, if part, or all, of the reduction sequences, such as carboxylic acid $\longrightarrow$ aldehyde $\longrightarrow$ primary alcohol $\longrightarrow$ alkane, ketone $\longrightarrow$ secondary alcohol $\longrightarrow$ alkane, tertiary alcohol $\longrightarrow$ alkane, occur on carbonaceous surfaces, it could significantly affect the oxidizing capacity of the atmosphere. It appears that the carbonaceous aerosol studies to date have omitted considering the possibility of such reactions taking place. These reduction sequences clearly include the increasingly high concentrations of the many halogenated carbonyl compounds produced by the degradation of 
hydrochloroflurocarbons (HCFCs), hydroflurocarbons (HFCs), halons, and chlorofluorocarbons (CFCs).

Acknowledgments. David Lary is an Alon Fellow and wishes to thank the Government of Israel for its support; he is also a Royal Society University Research Fellow and wishes to thank the Royal Society for its support. He also thanks J.A. Pyle for his support and Tony Cox for very useful conversations. R. Toumi thanks NEDO (Japan) for support. The Centre for Atmospheric Science is a joint initiative of the Department of Chemistry and the Department of Applied Mathematics and Theoretical Physics. This work forms part of the NERC UK Universities Global Atmospheric Modeling Programme.

\section{References}

Akhter, M. S., A. R. Chughtai, and D. M. Smith, Reaction of hexane soot with $\mathrm{NO}_{2} / \mathrm{N}_{2} \mathrm{O}_{4}, J$. Phys. Chem., 88(22), 5334-5342, 1984.

Akhter, M. S., A. R. Chughtai, and D. M. Smith, Aromaticity of elemental carbon (soot) by ${ }^{13} \mathrm{C} \mathrm{cp} / \mathrm{mas}$ and FTIR spectroscopy, Carbon, 23(5), 593-594, 1985a.

Akhter, M. S., J. R. Keifer, and A. R. Chughtai, and D. M. Smith, The absorption-band at $1590 \mathrm{~cm}^{-1}$ in the infraredspectrum of carbons, Carbon, 23(5), 589-591, 1985b.

Akhter, M. S., Chughtai, A. R., Smith, D. M.,The structure of hexane soot-I; Spectroscopic studies, Appl. Spectros., 39(1), 143-153, 1985c.

Akhter, M. S., A. R. Chughtai, and D. M. Smith, The structure of hexane soot-II; Extraction studies, Appl. Spectros., 39(1), 154-167, 1985d.

Akhter, M. S., A. R. Chughtai, and D. M. Smith, Determination of the integrated molar absorptivity for C-ONO and $\mathrm{C}^{-\mathrm{NO}_{2}}$ groups, using FTIR spectroscopy, Appl. Spectros., 40(7), 1068-1069, 1986.

Ammann, M., Heterogeneous interaction of $\mathrm{NO}_{2}$ with carbonaceous aerosols at the ppbv level: Adsorption, conversion to NO, production of HONO, paper presented at the $7^{\text {th }}$ European Symposium on Physico-Chemical behavior of atmospheric pollutants: The oxidizing capacity of the troposphere, Venice, Italy, October 2-4, 1996.

Ammann, M., U. Baltensperger, U. K. Bochert, B. Eichler, H. W. Gäggeler, D. T. Jost, A. Turler, and A.P. Weber, Study of $\mathrm{HI}, \mathrm{HBr}$ and $\mathrm{NO}_{2}$ adsorption on graphite and silver aerosol-particles using short-lived isotopes, J. Aerosol Sci., 26(1), 61-70, 1995.

Ammann, M., Baltensperger, U., Scherrer, P., Heterogeneous formation of nitrous acid on carbonaceous aerosol at very low nitrogen dioxide concentrations, Abst. Pap. Am. Chem. Soc., 214(Pt1), 6, 1997a.

Ammann, M., et al., Heterogeneous interaction of $\mathrm{NO}_{2}$ with carbonaceous aerosols at the ppb level: absorption, conversion to NO, production of $\mathrm{HONO}$, in The Oxidizing Capacity of the Troposphere, edited by B. Larsen, B. Versino, and G. Angeletti , EUR 17482, pp. 683-687, Eur. Comm. 1997b.

Ammann, M., M. Kalberer, D.T. Jost, L. Tobler, E. Rossler, D. Piguet, H.W. Gäggeler, and U. Baltensperger, Heterogeneous production of nitrous acid on soot in polluted air masses, Nature, 395(6698), 157-160, 1998.

Anderson, D. E., The troposphere to stratosphere radiation field at twilight: A spherical model, Planet. Space $S c i$, 31(12), 1517-1523, 1983.

Bastick, M., G. Dupupet, M. Marlot, J. M. Perrot, and J. Weber, Carbon, 15(25), 1977.

Bekki, S., The possible role of aircraft-generated soot in the middle latitude ozone depletion, J. Geophys. Res., 102(D9), 10751-10758, 1997.

Berezin, G. I., G. A. Petukhova, N. S. Polyakov, and M. L. Gubkina, Thermodynamic investigation of the state of water adsorbed by carbonaceous adsorbents Russ. Chem. Bull., 46(3), 443-447, 1997.

Blake, D. F., and K. Kato, Latitudinal distribution of black carbon soot in the upper troposphere and lower stratosphere, J. Geophys. Res., 100(D4), 7195-7202, 1995.

Chughtai, A. R., S. A. Gordon, and D. M. Smith, Kinetics of the hexane soot reaction with $\mathrm{NO}_{2} / \mathrm{N}_{2} \mathrm{O}_{4}$ at low concentration, Carbon, 32(3), 405-416, 1994.

Cope, M. J., Physical and chemical properties of coalified and charcoalified phytoclasts from some British Mesozoic sediments: An organic geochemical approach to paleobotany. Paper presented at the $9^{\text {th }}$ International Meeting on Organic Geochemistry, Newcastle-upon-Tyne, England, 1979.

de Vooys, F., The pore size distribution of activated carbon, in Activated carbon: A Fascinating Material, edited by A. Capelle, F. de Vooys, 13, Norit N.V., Amersfoort, The Netherlands, 1983.

Fisher, M., and D. J. Lary, Lagrangian four dimensional variational assimilation of chemical species, $Q$. J.R. Meteorol. Soc., 121(527), 1681-1704, 1995.

Gay, A. J. , R. F. Littlejohn, and P. J. Vanduin, Formation of carbonaceous cenospheres during fluidized-bed combustion of bituminous coals, Fuel, 62(10), 1224-1226, 1983.

Gay, A. J. , R. F. Littlejohn, and P. J. Vanduin, Studies of carbonaceous cenospheres from fluidized-bed combustors, Sci. Total Environ., 36, 239-246, 1984.

Gear, C.W., Numerical Initial Value Problems in Ordinary Differential Equations, Englewood Cliffs, N.J.: PrenticeHall, chap. 9, 1971.

Gereck, A., A. Thielmann, L. Gutzwiller, and M.J. Rossi, The chemical kinetics of HONO formation resulting from heterogeneous interaction of $\mathrm{NO}_{2}$ with flame soot, Geophys. Res. Lett., 25(13), 2453-2456, 1998.

Goldberg, E. D., Black carbon in the environment: Properties and distribution, John Wiley, New York, 1985.

Goss, K. U., and S. J. Eisenreich, Sorption of volatile organic compounds to particles from a combustion source at different temperatures and relative humidities, Atmos. Environ., 31(17), 2827-2834, 1997.

Gustafsson, O., F. Haghseta, C. Chan, J., MacFarlane, and P. M. Gschwend, Quantification of the dilute sedimentary soot phase: Implications for PAH speciation and bioavailability, Environ. Sci. Technol., 91(1), 203-209, 1997.

Hanson, D.R., A.R. Ravishankara, and S. Solomon, Heterogeneous reactions in sulfuric-acid aerosols - a framework for model-calculations, J. Geophys. Res., g9(D2), 36153629, 1994.

Harrison, R.M., and A.M.N. Kitto, Evidence for a surface source of atmospheric nitrous-acid, Atmos. Environ., 28(6), 1089-1094, 1994.

Hauglustaine, D. A., B. A. Ridley, S. Solomon, P.G. Hess, and $\mathrm{S}$. Madronich, $\mathrm{HNO}_{3} / \mathrm{NO}_{x}$ ratio in the remote troposphere during MLOPEX-2: Evidence for nitric-acid reduction on carbonaceous aerosols, Geophys. Res. Lett., 23(19), 2609-2612, 1996.

Jacob, D. J., et al., Origin of ozone and $\mathrm{NO}_{x}$ in the tropical troposphere - a photochemical analysis of aircraft observations over the south-atlantic basin, J. Geophys. Res., 101(D19), 24235-24250, 1996.

Jankowska, H., A. Swiatkowski, and J. Choma, Active Carbon, Ellis Horwood, Chichester, England, 1991.

Kalberer, M., Tabor, K., Ammann, M., Parrat, Y., Weingartner, E., Piguet, D, Rossler, E., Jost, D. T., Turler, A., Gäggeler, H. W., Baltensperger, U., Heterogeneous 
chemical-processing of ${ }^{13} \mathrm{NO}_{2}$ by monodisperse carbon aerosols at very-low concentrations, J. Phys. Chem., 100(38), 15487-15493, 1996.

Karcher, B., Aircraft-generated aerosols and visible contrails, Geophys. Res. Lett., 23(15), 1933-1936, 1996.

Karcher, B., T. Peter, U. M. Biermann, and U. Schumann, The initial composition of jet condensation trails, $J$. Atmos. Sci., 53(21), 3066-3083, 1996.

Keifer, J.R., M. Novicky, M.S. Akhter, A.R. Chughtai, and D.M. Smith, The nature and reactivity of the elemental carbon (soot) surface as revealed by fourier-transform infrared (FTIR) spectroscopy, Proc. Soc. Photo-Opt. Instrum. Eng., 289, 184-188, 1981.

Kinoshita, K., Carbon: Electrochemical and Physicochemical Properties, John Wiley, New York, 1988.

Konopka, P., and W. Vogelsberger, Kohler equation for finite systems: A simple estimation of possible condensation mechanisms in aircraft contrails, J. Geophys. Res., 102(D13), 16057-16064, 1997.

Kotzick, R., U. Panne, and R. Niessner, Changes in condensation properties of ultrafine carbon particles subjected to oxidation by ozone, J. Aerosol Sci., 28(5), 725-735, 1997.

Lammel, G., and T. Novakov, Water nucleation properties of carbon-black and diesel soot particles, Atmos. Environ., 29(7), 813-823, 1995.

Lary, D. J. and J. A. Pyle, Diffuse radiation, twilight and photochemistry - I, J. Atmos. Chem., 13, 373-392, 1992a.

Lary, D. J. and J. A. Pyle, Diffuse radiation, twilight and photochemistry - II, J. Atmos. Chem., 13, 393-406, 1992 b.

Lary, D. J., R. Toumi, A. M. Lee, M. J. Newchurch, M. Pirre, and J. B. Renard, Carbon aerosols and atmospheric photochemistry, J. Geophys. Res., Atmospheres, 102(D3), 3671-3682, 1997.

Long, F.J., and K.W. Sykes, The mechanism of the steamcarbon reaction, Proc. Roy. Soc. of London, Sec. A, 193, 377-399, 1948.

Mahajan, O. P., A. Youseff, and P. L. Walker, Separation Sci. Technol., 13, 487, 1978.

Mantell, C. L., Carbon and Graphite Handbook, Interscience, New York, 1968.

Mattson, J. S., H. B., Mark, Activated Carbon, Marcel Dekker, New York, 1971.

McDow, S.R., M.S. Jang, Y. Hong, and R.M. Kamens, An approach to studying the effect of organic composition on atmospheric aerosol photochemistry, J. Geophys. Res.Atmospheres, 101(D14), 19593-19600, 1996.

Medalia, A. I., Rivin, D., Forms of particulate carbon in soot and carbon-black, Carbon, 20(2), 152, 1982.

Medalia, A. I., and D. Rivin, Particulate carbon and other components of soot and carbon-black, Corbon, 20(6), 481492,1982

Medalia, A. I., D. Rivin, and D.R. Sanders, A comparison of carbon-black with soot, Rubber Chem. Technol., 55(1), 257-258, 1982.

Medalia, A. I., D. Rivin, and D.R. Sanders, A comparison of carbon-black with soot, Sci. Total Environ., 31(1), 1-22, 1983.

Meier, R. R., D. E. Anderson, and M. Nicolet, The radiation field in the troposphere and stratosphere from $240 \mathrm{~nm}$ to 1000 nm: General analysis, Planet. Space Sci., 30(9), 923933, 1982.

Nicolet, M., R. R. Meier, and D. E. Anderson, The radiation field in the troposphere and stratosphere from $240 \mathrm{~nm}$ to 1000 nm: Numerical analysis, Planet. Space Sci., 30(9), 935-983, 1982.

Noh, J.S., and J.A. Schwarz, Effect of $\mathrm{HNO}_{3}$ treatment on the surface-acidity of activated carbons, Carbon, 28(5), 675-682, 1990.

Pires, M., H. VandenBergh, and M.J. Rossi, The heterogeneous formation of $\mathrm{N}_{2} \mathrm{O}$ over bulk condensed phases in the presence of SO2 at high humidities, J. Atmos. Chem., 25(3), 229-250, 1996.

Press W.H., S.A. Teukolsky, W.T. Vetterling, and B.P. Flannery, Numerical Recipes in Fortran: The Art of Scientific Computing, $2^{\text {nd }}$ edition, Cambridge Univ. Press, New York 1992.

Rogaski, C.A., D.M. Golden, and L.R. Williams, Reactive uptake and hydration experiments on amorphous carbon treated with $\mathrm{NO}_{2}, \mathrm{SO}_{2}, \mathrm{O}_{3}, \mathrm{HNO}_{3}$, and $\mathrm{H}_{2} \mathrm{SO}_{4}$, Geophys. Res. Lett., 24(4), 381-384, 1997.

Seinfeld, J. H., Atmospheric Chemistry and Physics of Air Pollution, Wiley Interscience, 1986.

Sergides, C.A., J.A., Jassim, A.R., Chughtai, and D.M. Smith, The structure of hexane soot, 3,Ozonation studies, Appl. Spectros., 41(3), 482-492, 1987.

Smisek, M., and S. Cerny, Active Carbon, Elsevier, New York, 1970.

Smith, D.M., and A.R. Chughtai, The surface-structure and reactivity of black carbon, Colloids Surf. A, 105(1), 47-77, 1995.

Smith, D.M., and A.R. Chughtai, Reaction-kinetics of ozone at low concentrations with n-hexane soot, $J$. Geophys. Res., 101(D14), 19607-19620, 1996.

Smith, D.M., and A.R. Chughtai, Photochemical effects in the heterogeneous reaction of soot with ozone at low concentrations, J. Atmos. Chem., 26(1), 77-91, 1997

Smyth, S. B., et al., Factors influencing the upper free tropospheric distribution of reactive nitrogen over the South Atlantic during the TRACE A experiment J. Geophys. Res., 101(D19), 24165-24186, 1996.

Stoer, J., and R. Bulirsch, Introduction to Numerical Analysis, Springer-Verlag, New York, chap. 7, 1980.

Tabor, K., L. Gutzwiller, and M. J. Rossi, The heterogeneous interaction of $\mathrm{NO}_{2}$ with amorphous-carbon, Geophys. Res. Lett., 20(14), 1431-1434, 1993.

Tabor, K., L. Gutzwiller, and M. J. Rossi, The heterogeneous interaction of $\mathrm{NO}_{2}$ with amorphous-carbon at ambient temperature, J. Phys. Chem., 98(24), 6172-6186, 1994.

Thlibi, J., and J. C. Petit, A study of the $\mathrm{NO}_{y} /$ Soot interaction in the temperature range $303-1223 \mathrm{~K}$, paper presented at International Scientific Colloquium, Cologne, Germany, April 18-20, 1994.

van der Plas, Th., The texture and the surface chemistry of carbons, in Physical and Chemical Aspects of Adsorbents and Catalysts, chap. 9, pp. 425-469, Academic Press, San Diego, Calif., 1970.

van Driel, J., Surface chemistry of activated carbon, in Activated carbon: A Fascinating Material, edited by A. Capelle, F. de Vooys, Norit N.V., Amersfoort, The Netherlands, 1983.

D. J. Lary, Department of Geophysics and Planetary Sciences, Tel Aviv University, 69978, Tel Aviv, Israel.

D. E. Shallcross, Centre for Atmospheric Science, Department of Chemistry, Cambridge University, Cambridge, CB2 1EW, England, U.K.

R. Toumi, Department of Physics, Imperial College, London, SW7 2BZ, England, U.K.

(Received June 11, 1998; revised December 1, 1998; accepted December 4, 1998.) 